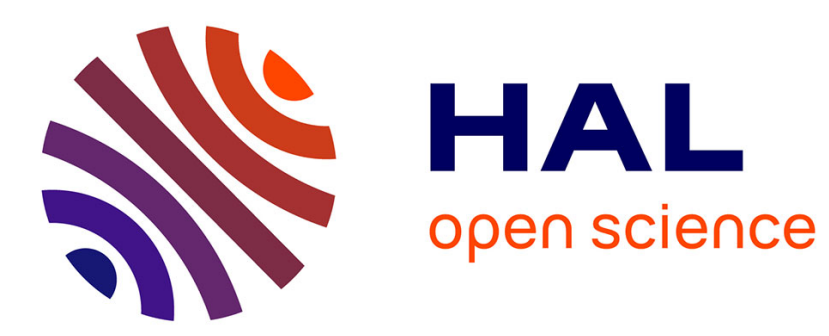

\title{
Marathon progress : demography, morphology and environment
}

\author{
Andy Marc, Adrien Sedeaud, Marion Guillaume, Mélissa Rizk, Julien \\ Schipman, Juliana Antero, Amal Haïda, Geoffroy C.B. Berthelot, \\ Jean-François Toussaint
}

\section{To cite this version:}

Andy Marc, Adrien Sedeaud, Marion Guillaume, Mélissa Rizk, Julien Schipman, et al.. Marathon progress : demography, morphology and environment. Journal of Sports Sciences, 2014, 32 (6), pp.524532. 10.1080/02640414.2013.835436 . hal-01774199

\section{HAL Id: hal-01774199 https://hal-insep.archives-ouvertes.fr/hal-01774199}

Submitted on 27 Apr 2018

HAL is a multi-disciplinary open access archive for the deposit and dissemination of scientific research documents, whether they are published or not. The documents may come from teaching and research institutions in France or abroad, or from public or private research centers.
L'archive ouverte pluridisciplinaire $\mathbf{H A L}$, est destinée au dépôt et à la diffusion de documents scientifiques de niveau recherche, publiés ou non, émanant des établissements d'enseignement et de recherche français ou étrangers, des laboratoires publics ou privés. 


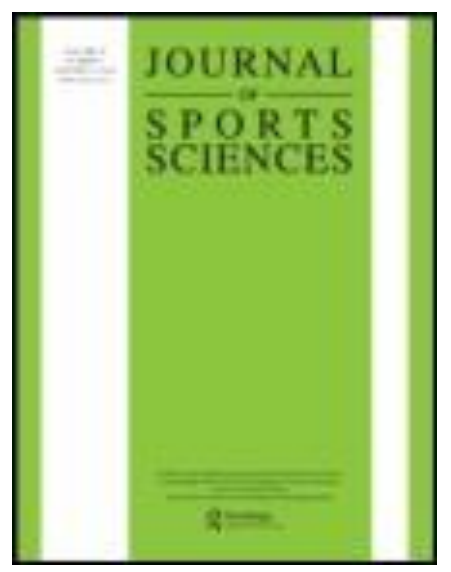

\section{Journal of Sports Sciences}

\section{Marathon progress: demography, morphology and environment}

Andy Marc ${ }^{\mathrm{a}}$, Adrien Sedeaud ${ }^{\mathrm{ab}}$, Marion Guillaume ${ }^{\mathrm{a}}$, Melissa Rizk ${ }^{\mathrm{a}}$, Julien Schipman ${ }^{\mathrm{a}}$, Juliana Antero-Jacquemin $^{\mathrm{a}}$, Amal Haida ${ }^{\mathrm{a}}$, Geoffroy Berthelot ${ }^{\mathrm{ab}}$ \& Jean-François Toussaint ${ }^{\mathrm{abc}}$

${ }^{a}$ Irmes (Institut de Recherche bioMédicale et d'Epidémiologie du Sport), Insep (Institut National du Sport, de l'Expertise et de la Performance), Paris, France

${ }^{\mathrm{b}}$ Université Paris Descartes Sorbonne Paris Cité, Paris, France

${ }^{\mathrm{c}}$ CIMS, Hôtel-Dieu, Paris, France 


\title{
Marathon progress: demography, morphology and environment
}

\author{
ANDY MARC ${ }^{1}$, ADRIEN SEDEAUD $^{1,2}$, MARION GUILLAUME ${ }^{1}$, MELISSA RIZK $^{1}$, \\ JULIEN SCHIPMAN ${ }^{1}$, JULIANA ANTERO-JACQUEMIN ${ }^{1}$, AMAL HAIDA $^{1}$, \\ GEOFFROY BERTHELOT ${ }^{1,2}$, \& JEAN-FRANÇOIS TOUSSAINT ${ }^{1,2,3}$
}

\author{
${ }^{1}$ Irmes (Institut de Recherche bioMédicale et d'Epidémiologie du Sport), Insep (Institut National du Sport, de l'Expertise et de \\ la Performance), Paris, France, ${ }^{2}$ Université Paris Descartes Sorbonne Paris Cité, Paris, France, and ${ }^{3}$ CIMS, Hôtel-Dieu, \\ Paris, France
}

\begin{abstract}
As opposed to many other track-and-field events, marathon performances still improve. We choose to better describe the reasons for such a progression. The 100 best marathon runners archived from January 1990 to December 2011 for men and from January 1996 to December 2011 for women were analysed. We determined the impact of historical, demographic, physiological, seasonal and environmental factors. Performances in marathons improve at every level of performance (deciles). In 2011, 94\% of the 100 best men athletes were African runners; among women athletes they were 52\%. Morphological indicators (stature, body mass and Body Mass Index (BMI)) have decreased. We show a parabolic function between BMI and running speed. The seasonal distribution has two peaks, in spring (weeks 14 to 17) and autumn (weeks 41 to 44). During both periods, the average temperature of the host cities varies close to optimal value for long distance race. African men and women runners are increasingly dominating the marathon and pushing its record, through optimal ecophysiological conditions.
\end{abstract}

Keywords: Marathon, performance, demography, morphology, environment

\section{Introduction}

Completion of a marathon in less than $2 \mathrm{~h}$ is yet to occur. Joyner, Ruiz, and Lucia (2011) estimated that this time limit might be broken by about 2021, with an improvement of $10 \mathrm{~s}$ per year until then. The quest to break this record has been on in all five continents for some 40 years. During this time there has been a marked increase in the number of races that occur annually (644 in 1990 to 2820 in 2011) and the number of participants $(234,000$ registered in 1990 and 1.48 million in 2011) have also increased (Association of Road Racing Statisticians ARRS, s. d.). Coincidentally, new world records in trackand-field have become scarcer. For example, $64 \%$ of track-and-field events have had no new records since 1993 (Berthelot et al., 2010). A new world marathon record was set in September 2011 in Berlin by Patrick Makau, a Kenyan runner, in $2 \mathrm{~h} 3 \mathrm{~min}$ and $38 \mathrm{~s}$.

Individual performance depends on endogenous factors such as anthropometric, genetic and physiological characteristics (Lippi, Favaloro, \& Guidi, 2008; Macarthur \& North, 2005) and environmental factors that affect all athletes (El Helou et al., 2012; Ely, Cheuvront, Roberts, \& Montain, 2007; Galloway \& Maughan, 1997; Vihma, 2010). Globally, the number of participants has increased and so presented a larger genetic diversity in this event. However, the best performances are mainly achieved by runners originating from East Africa who possess physiological characteristics that allow higher standards of performance. Furthermore, the marathon is a track-and-field discipline that is affected by environmental conditions such as temperature, humidity, pollutants, atmospheric pressure and winds. Among these factors, temperature appears to have most influence on performance (El Helou et al., 2012). Because of cultural, mediarelated and commercial reasons, prestigious international competitions such as the Olympic Games and World Championships, are held in the summer (July and August), under warm and less favourable conditions. The objective of this study is to identify factors that influence best performances in the marathon, considering historical, demographic,

Correspondence: Andy Marc, Irmes (Institut de Recherche bioMédicale et d'Epidémiologie du Sport), Insep (Institut National du Sport, de l'Expertise et de la Performance), 11 avenue du tremblay, Paris, France. E-mail: andy.marc@insep.fr 
anthropometrical and seasonal characteristics for the 100 yearly best performers from 1990 to 2011. This could allow the identification of the most appropriate profiles as well as the most favourable conditions.

\section{Method}

\section{Data collection}

We collected the results of the top 100 world best performers each year from January 1990 to December 2011 for men and from January 1996 to December 2011 for women. This produced a total of 3800 results (2200 for men and 1600 for women) collected from the open-access website http://www.iaaf.org/. For inclusion, men had to have completed races in less than $2 \mathrm{~h} 18 \mathrm{~min}$, while the equivalent for women was less than 2 h 34 min. For each athlete, birth date, nationality, date and place of the event, race time (converted into speed, in $\mathrm{m} \cdot \mathrm{s}^{-1}$ ), plus stature and body mass were recorded. BMI was calculated.

\section{Running speed}

For men and women, the groups of the 100 top performers were categorised into speed deciles. For each year and each group, the mean and confidence intervals were calculated for each decile and for both sexes as a basis for comparison (equation and coefficient of determination were calculated for men and women).

A Student test was performed to compare the speed of runners integrating the top 100 in 1990 for men and 1996 for women to the speed of those integrating the top 100 in 2011.

\section{Demography}

Athletes' nationalities were categorised into one of the six world regions: Africa, Asia, Europe, North America, South America and Oceania. For each year and both sexes, the contribution of each continent in the top 100 was calculated. One-way between groups ANOVA compared means of the 10 best performers of each continent and identified demographic trends for both sexes. Then, the means of the 10 best performers of each continent were also compared in pairs for both the sexes using a Mann-Whitney test because the sample does not follow a normal distribution and $n$ is less than 30 (Table I).

\section{Morphology}

The mean and confidence intervals for the top 100 men runners by year were calculated, and a Student Test was performed to compare the stature, body mass and BMI of runners integrating the Top 100 in 1990 for men and 1996 for women to those integrating the Top 100 in 2011.

Then, we determined if there was a correlation between BMI and running speed to complete a marathon. This was done by identifying the maximal running speed for each BMI.

\section{Seasonal performance}

For races between 1990 and 2011 for men and 1996 and 2011 for women, we analysed the number of performances for each week of the year (2200 for men and 1600 for women). The weekly percentage of performances of the total was calculated for both sexes to compare seasonal effects:

$$
\frac{n \text { (number of performance by week }) * 100}{N(\text { total })}
$$

Statistical analyses were performed with the R software. Statistical significance was considered at $P<0.05$. Effect size for One-Way ANOVA was Cohen's d and evaluated with Cohen's conventional criteria (Field, 2009). For Mann-Whitney test, the formula for the calculation of effect size is $r=Z / \sqrt{ } N$, with criteria evaluation: $\operatorname{abs}(r)=0.1$ small size, $\operatorname{abs}(r)$ $=0.3$ medium size, $\operatorname{abs}(r)=0.5$ large size .

\section{Results}

\section{Running speed}

The mean running speed of the top 100 performers has continually increased since 1990 for men and since 1996 for women in all deciles with at least $P<0.001$ for men (decile10) and $P<0.02$ (decile1) for women. For men, the mean speed was of $5.30 \pm 0.08 \mathrm{~m} \cdot \mathrm{s}^{-1}$ in 1990 and $5.52 \pm 0.06 \mathrm{~m} \cdot \mathrm{s}^{-1}$ in 2011, $P<0.001$. For women, this trend was similar and rose from a mean speed of $4.68 \pm 0.06 \mathrm{~m} \cdot \mathrm{s}^{-1}$ in 1996 to $4.85 \pm 0.07 \mathrm{~m} \cdot \mathrm{s}^{-1}$ in $2011, P<0.001$. Each year, the best performances of the Top 100 men marathoners were run in $31 \pm 5$ races. Their mean ranking at the end of each race in which they were engaged was $4 \pm 3$. The best performances of the top 100 women runners occurred in $31 \pm 3$ races. Their mean ranking was $4 \pm 3$. Annual modifications in running speed for both sexes were similar for all decile groups throughout the study period (Figures 1 (a) and (b)).

\section{Demography}

Top 100. Since 1990, 55\% of men's performances were attributable to African runners (of these, $83 \%$ were from Kenya and Ethiopia), 24\% were from Europe and 15\% were from Asia. Since 1996, 39\% 
Table I. Mean speed of top 10 athletes by continents and sexes, statistically comparing by a test of mean ranks - Mann-Whitney test for men and women.

\begin{tabular}{|c|c|c|c|c|c|c|c|}
\hline Sex & Region & Mean \pm SD & $p$-value Africa & Europe & Asia & South America & North America \\
\hline \multirow[t]{6}{*}{ Men } & Africa & $5.67 \pm 0.03$ & & & & & \\
\hline & Europe & $5.53 \pm 0.02$ & $* * *$ & & & & \\
\hline & Asia & $5.52 \pm 0.03$ & $* * *$ & 0.153 & & & \\
\hline & South America & $5.49 \pm 0.05$ & $* * *$ & $*$ & 0.057 & & \\
\hline & North America & $5.47 \pm 0.08$ & $* * *$ & $*$ & $*$ & $*$ & \\
\hline & Oceanic & $5.39 \pm 0.05$ & $* * *$ & $* * *$ & $* * *$ & $* *$ & $* *$ \\
\hline \multirow[t]{6}{*}{ Women } & Africa & $5.00 \pm 0.04$ & & & & & \\
\hline & Europe & $5.00 \pm 0.08$ & NS & & & & \\
\hline & Asia & $4.99 \pm 0.05$ & NS & 0.82 & & & \\
\hline & South America & $4.75 \pm 0.09$ & $* * *$ & $* * *$ & $* * *$ & & \\
\hline & North America & $4.82 \pm 0.10$ & $* *$ & $* *$ & $* *$ & 0.081 & \\
\hline & Oceanic & $4.76 \pm 0.09$ & $* * *$ & $* * *$ & $* * *$ & NS & 0.14 \\
\hline
\end{tabular}

Note: ${ }^{*}<0.05 ;{ }^{* *}<0.01 ;$ and ${ }^{* * *}<0.001$.

For Men:

For women:

Africa VS Europe:

$U=100, Z=3.82, P<0.001, r=0.85 ; \quad U=60.5, Z=0.81, P=0.44, r=0.18$;

Africa VS Asia:

$U=100, Z=3.80, P<0.001, r=0.85 ; \quad U=60, Z=0.76, P=0.47, r=0.17$

Africa VS South America:

$U=100, Z=3.80, P<0.001, r=0.85 ; \quad U=100, Z=3.80, P<0.001, r=0.85$;

Africa VS North America:

$U=99, Z=3.72, P<0.001, r=0.83$;

Africa VS Oceania:

$U=100, Z=3.79, P<0.001, r=0.85$;

Europe VS Asia:

$U=31, Z=-1.47, P=0.15, r=0.33$;

Europe VS South America:

$U=22.5, Z=-2.12, P<0.05, r=0.47 ; \quad U=0.5, Z=-3.75, P<0.001, r=0.84$;

Europe VS North America:

$U=20, Z=-2.29, P<0.05, r=0.51$;

Europe VS Oceania:

$U=100, Z=3.82, P<0.001, r=0.86$;

Asia VS South America:

$U=0, Z=-1.94, P=0.06, r=0.43$;

Asia VS North America:

$U=20, Z=-2.28, P<0.05, r=0.51$;

Asia VS Oceania:

$U=100, Z=3.80, P<0.001, r=0.85$;

South America VS North America:

$U=24, Z=-1.98, P<0.05, r=0.44 ; \quad U=73.5, Z=1.78, P=0.08, r=0.40$;

South America VS Oceania:

$U=93.5, Z=3.31, P<0.01, r=0.74 ; \quad U=45, Z=-0.38, P=0.73, r=0.09$;

North America VS Oceania:

$U=84.5, Z=2.63, P<0.01, r=0.59 . \quad U=70, Z=1.52, P=0.14, r=0.34$.

of women's performances were by Europeans, 30\% by Asians and $24 \%$ by Africans runners. These percentages have continually evolved (Figure 2 (a) and (b)). For women, the percentage of African runners increased from $6 \%$ in 1996 to $52 \%$ in 2011. Likewise, for men, the percentage of African runners increased from $16 \%$ in 1990 to $94 \%$ in 2011. As a result, the demographic contribution of other regions has progressively decreased; the percentage of European women runners was $48 \%$ in 1996 but only $24 \%$ in 2011 . For men, the proportion of European runners reduced from $47 \%$ in 1990 to $0 \%$ in 2011. The crossing point showing the start of African dominance in the top 100 appeared in
1996 for men. For women, this crossing point occurred 13 years later, in 2009.

Top 10 men and women performers for each continent

Men nationalities in each continental top 10 . There are two nationalities for Africa (8 Kenyan and 2 Ethiopian), six for Europe (5 French, 1 Ukrainian, 1 Italian, 1 Portuguese, 1 Belgian and 1 Swiss), two for Asia (8 Japanese and 2 South Korean), two for South America (6 Mexican and 4 Brazilian), two for Oceania (8 Australian and 2 New Zealander) and only one nationality for North America (10 USA). 

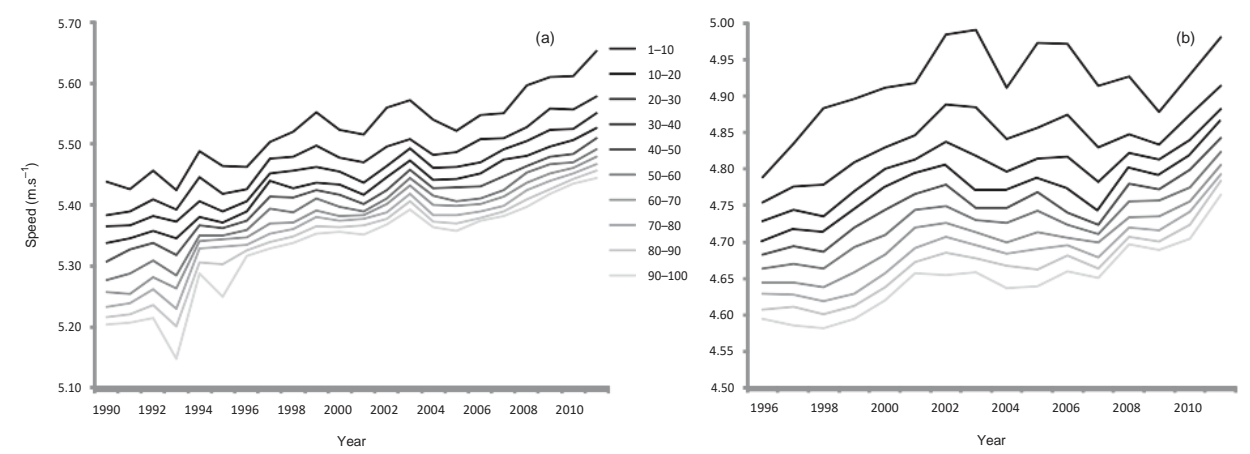

Figure 1. Mean race speeds by season for each decile from the top 100: (a) 1990 to 2011 for men; (b) 1996 to 2011 for women.

Note:

For men:

$\mathrm{y}_{1}=-12.56+0.009 \mathrm{x} ; R^{2}=0.87 ;$

$\mathrm{y}_{2}=-10.70+0.008 \mathrm{x} ; R^{2}=0.90$

$\mathrm{y}_{3}=-10.38+0.007 \mathrm{x} ; R^{2}=0.91 ;$

$\mathrm{y}_{4}=-10.66+0.008 \mathrm{x} ; R^{2}=0.91 ;$

$\mathrm{y}_{5}=-10.93+0.008 \mathrm{x} ; R^{2}=0.91 ;$

$\mathrm{y}_{6}=-12.33+0.008 \mathrm{x} ; R^{2}=0.89$;

$\mathrm{y}_{7}=-13.45+0.009 \mathrm{x} ; R^{2}=0.89 ;$

$\mathrm{y}_{8}=-14.26+0.009 \mathrm{x} ; R^{2}=0.87$;

$\mathrm{y}_{9}=-15.56+0.010 \mathrm{x} ; R^{2}=0.87$

$\mathrm{y}_{10}=-17.40+0.011 \mathrm{x} ; R^{2}=0.84$.

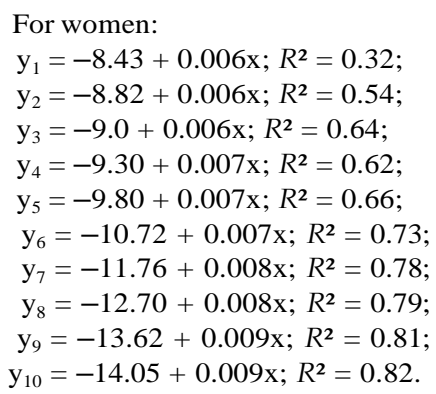

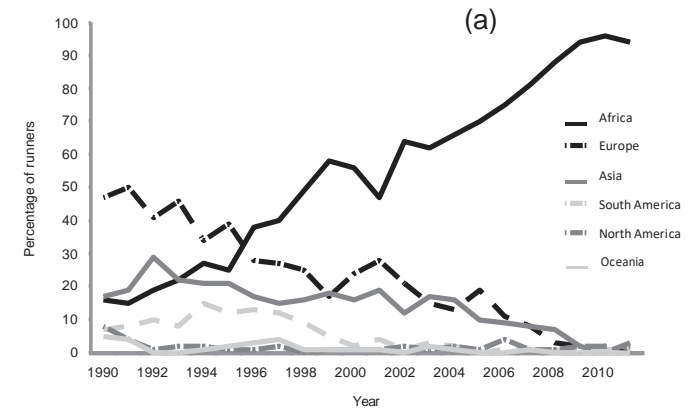

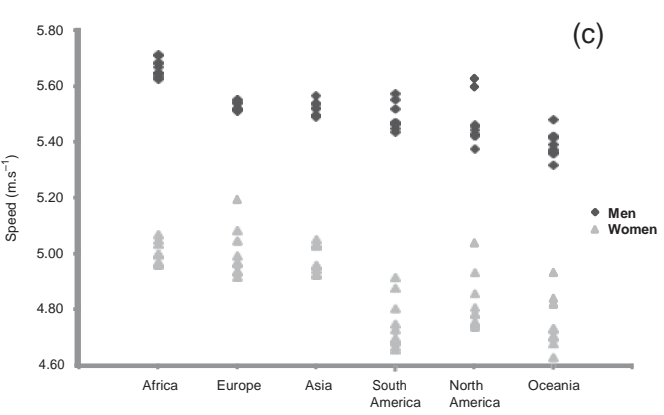

(b)

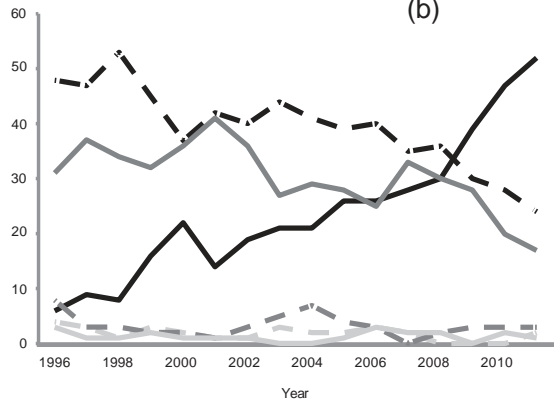



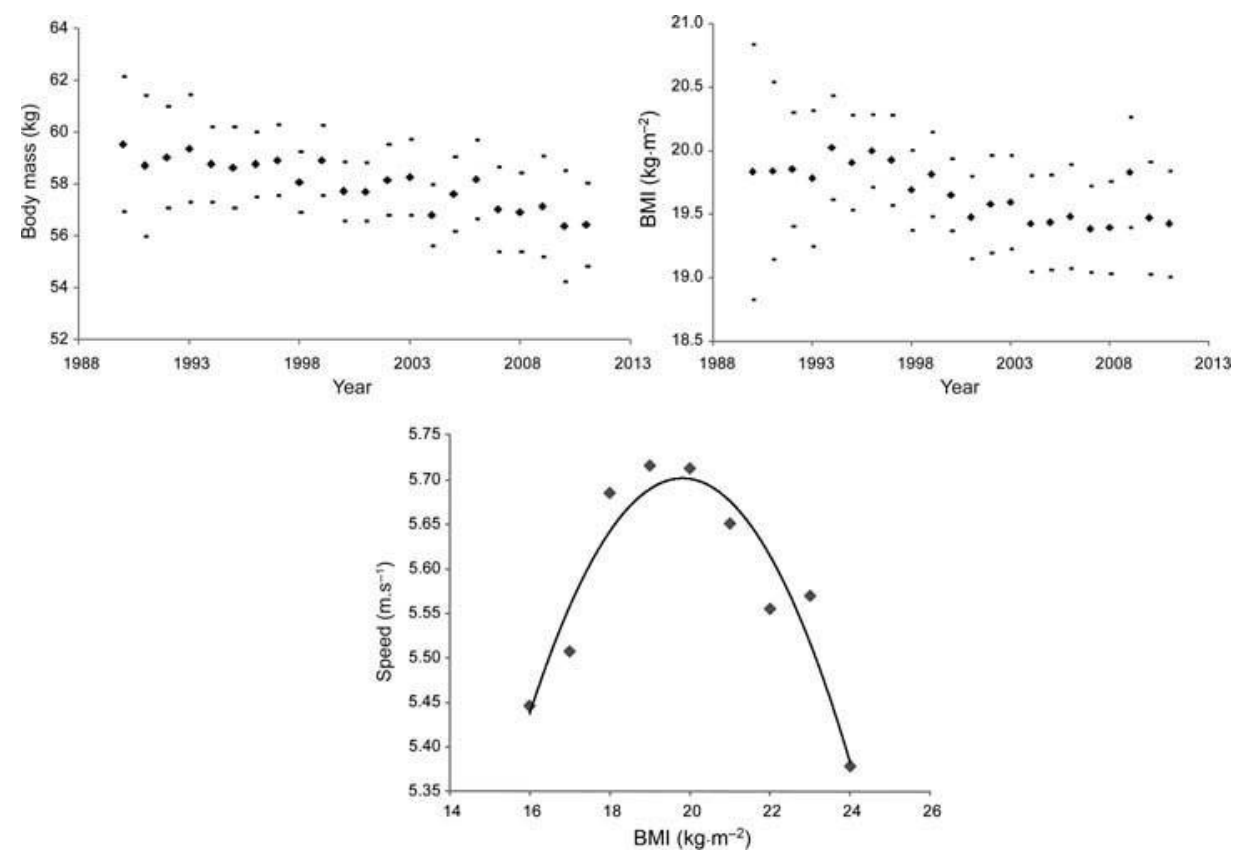

Figure 3. Mean body mass (a) and BMI (b) of the Top 100 men runners and its standard deviation by season (1990 to 2011) (c) Race speed record of the Top 100 men runners by BMI. Modelling function: $y=-1.4387+0.7208 x-0.0182 x 2$ and $R^{2}=0.89$.

Mean speed of the African 10 best is $5.67 \pm 0.03 \mathrm{~m} \cdot \mathrm{s}^{-1}$. These runners are faster than all others competitors (Figure 2 (c) and Table I). The 10 best European and Asian men runners have similar performances with a mean race speed of $5.53 \pm 0.02 \mathrm{~m} \cdot \mathrm{s}^{-1}$ and $5.52 \pm 0.03 \mathrm{~m} \cdot \mathrm{s}^{-1}$, respectively. In contrast, for women runners, this distribution was less variable across regions (ANOVA women $P<0.001$; effect size 0.50 ). The mean performance for the 10 best African runners was $5.00 \pm 0.04 \mathrm{~m} \cdot \mathrm{s}^{-1}$, it is $5.00 \pm 0.08 \mathrm{~m} \cdot \mathrm{s}^{1}$ for Europeans and $4.99 \pm 0.05 \mathrm{~m} \cdot \mathrm{s}^{-1}$ for Asian runners. However, the athletes from other continents, such as South America, North America and Oceania, have mean speeds of $4.75 \pm 0.09 \mathrm{~m} \cdot \mathrm{s}^{-1}, 4.82 \pm 0.1 \mathrm{~m} \cdot \mathrm{s}^{-1}$ and $4.76 \pm 0.09 \mathrm{~m} \cdot \mathrm{s}^{-1}$, respectively. They are slower than athletes from Africa, Europe and Asia $P<0.01$.

\section{Morphology and running speed of the Top 100 performers}

For men, stature, body mass and BMI decreased from 1990 to 2011 (Figure 3 (a) and (b)). Over the entire study period, the stature of the runners ranged from 156 to $190 \mathrm{~cm}$, the body mass from 45 to $78 \mathrm{~kg}$ and BMI ranged from 15.78 to $23.05 \mathrm{~kg} / \mathrm{m}^{2}$. The mean body mass for men decreased significantly from $59.6 \pm 2.30 \mathrm{~kg}$ in 1990 to $56.2 \pm 1.10 \mathrm{~kg}$ in $2011(P<0.01)$. The mean BMI also decreased significantly from $19.83 \pm 1.70 \mathrm{~kg} / \mathrm{m}^{2}$ in 1990 to $19.42 \pm 1.30 \mathrm{~kg} / \mathrm{m}^{2}$ in 2011 .

In addition, BMI and maximal race speeds were correlated. When modelled with a second-order polynomial function $(y=-1.4387+0.7208 x-$
$0.0182 x^{2}, R^{2}=0.89$ ), the optimal BMI for men was $19.8 \mathrm{~kg} \cdot \mathrm{m}^{2}$ for a maximal speed of $5.70 \mathrm{~m} \cdot \mathrm{s}^{-1}$. Equivalents for women were $18.2 \mathrm{~kg} \cdot \mathrm{m}^{2}$ and $5.19 \mathrm{~m} \cdot \mathrm{s}^{-1}$ (Figure 3 (c)).

\section{Seasonality}

Annual performances spread over 50 weeks for men and 47 weeks for women. The distribution shows two peaks. The first peak occurs in weeks 14, 15, 16 and 17 (April) while the second occurs during weeks 41, 42, 43 and 44 (October) (Figure 4). These eight weeks contain $48.7 \%$ of women's performances $(27.6 \%$ for April and $21.1 \%$ for October) and $54.4 \%$ of men's performance (29.4\% for April and $25.0 \%$ for October). Performances during weeks 25 to 32 (from early June to late August) represent less than $1 \%$ of the total.

\section{Discussion}

Our study is the first to analyse the overall pattern of elite-standard men and women marathoners over the last 25 years to identify factors that influence performance.

\section{Race speeds}

This study shows that marathon performances improved for each decile and for both sexes among the annual 100 best runners. This contrasts with sports performances in general that have tended to 


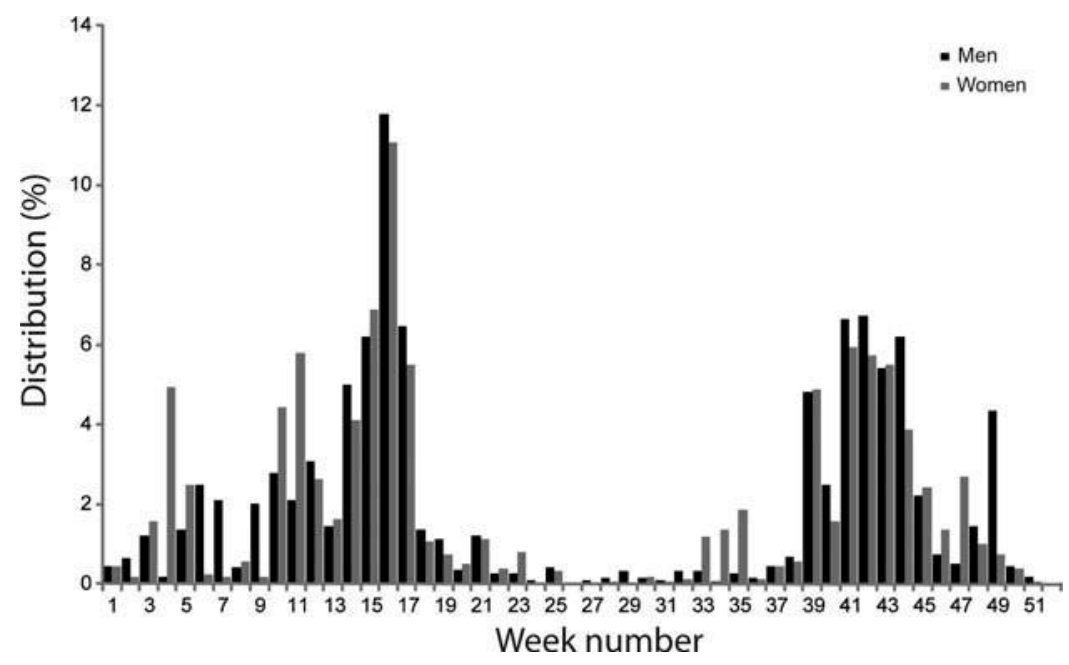

Figure 4. Percentage distributions of the 2200 performances collected from the top 100 of each year of the season (1990 to 2011 ) for men represented by black columns. Percentage distributions of the 1600 performances collected from the top 100 of each year of the season (1996 to 2011) for women represented by grey columns.

reach a limit; $64 \%$ of track-and-field events have not improved since 1993 (Berthelot et al., 2010; Nevill \& Whyte, 2005). Moreover, this trend is apparent in many other sports where best performances have stagnated (Berthelot et al., 2008; Desgorces et al., 2008). This might be because of saturation effects, i.e. interactions between genomics (Macarthur \& North, 2005; Williams \& Folland, 2008), physiology, demography and environmental factors (Desgorces et al., 2008; El Helou et al., 2012). Notably, annual variations in race speeds were similar for each decile. When the first decile (Top 10 speed races) increased or decreased, the last decile (Top 90-100 speed races) varied in the same way. These variations could be associated with mean seasonal climatic conditions recorded in the host cities. This probably explains why the best performances of the top 100 men and women marathoners are accomplished each year in a mean of $31 \pm 5$ races (in different cities) for men and $31 \pm 3$ for women (Association of Road Racing Statisticians ARRS, s. d.).

\section{Demography}

The best performances by men in marathons were by athletes from East Africa (mainly Kenya and Ethiopia) and this trend has been progressive from 1990 to 2011 (16\% to 94\%). Conversely, other nationalities, initially dominant in the list of top 100 performers (from Europe, Asia, South America, North America and Oceania), are increasingly less prominent over the same period, $84 \%$ in 1990 to $6 \%$ in 2011 . This change in domination also occurred in the speed of the 10 best performers from each continent since 1990 . While the top 10 African runners ran at a mean speed of $5.68 \pm 0.03 \mathrm{~m} \cdot \mathrm{s}^{-1}$, other top 10 runners from other continents were slower $\left(5.48 \pm 0.07 \mathrm{~m} \cdot \mathrm{s}^{-1}\right)$ during the same period. Several studies have attempted to explain the success of Africans. One of the reasons for the dominance could be their physiological characteristics. Despite comparable maximum oxygen uptake, Africans tend to run at a higher percentage of their maxima during competition than Europeans. This results in improved economy (Bosch, Goslin, Noakes, \& Dennis, 1990; Larsen, 2003). Kenyan runners also have greater activity of the $\beta$-oxidative enzyme HAD (3-hydroxyacyl- CoA-dehydrogenase activity) in their muscles (Saltin, Kim, et al., 1995; Weston, Karamizrak, Smith, Noakes, \& Myburgh, 1999). Other authors have shown that sporting ability is characterised by specific genotypes that still need to be identified. Macarthur and North (2005) showed that variation in human performance and athletic ability has long been recognised as having a strong heritable component. Indeed, Rivera et al. (1997) demonstrated strong associations between a restriction fragment length polymorphism in muscle-specific creatine kinase and the response of maximal oxygen uptake $\left(\mathrm{VO}_{2} \max \right)$ after 20 weeks of endurance training in 240 unrelated members of the heritage family cohort. East African runners also exhibited greater fatigue resistance (Coetzer et al., 1993). Furthermore, (Onywera, Scott, Boit, \& Pitsiladis, 2006), reported that Kenyan runners differed from the general population because of greater physical activity during childhood and adolescence during their travels to school. A higher proportion of athletes had run to school each day (controls 22\%, national athletes $73 \%$ and international athletes $81 \%$ ) and covered greater distances than other groups. It has been shown that Kenyan boys who 
travelled to school by walking and running had $30 \%$ greater $\mathrm{VO}_{2} \max$ than those who did not (Saltin, Larsen, et al., 1995) and those results were confirmed for Ethiopian runners (Scott et al., 2003). Also, chronic altitude exposure, as experienced by many young East African runners, combined synergistically with endurance training to induce haematological adaptations, which partially accounted for their greater physiological capabilities (Schmidt et al., 2002). However, despite a marked increase in number of African athletes in the world-best performances in recent years, African women runners' superiority is not as strongly established as for men (in 2011, 94\% in men as opposed to $52 \%$ in women). For performance during the study period, the 10 best race speeds of African women were not greater than those in runners from Europe and Asia.

This difference could be explained by their later and gradual arrival in this activity. Indeed, the increase of women's participation in the Olympic Games has grown from only $1.9 \%$ in 1900 to 42.3\% in 2008 in Beijing (Olympics at Sports Reference, s. d.). In particular for the marathon, the first appearance of women occurred less than 30 years ago in the Los Angeles Olympic Games of 1984 (O'Brien, 1985). Today, women's mean participation in international marathons is $33 \%$ (Association of Road Racing Statisticians ARRS, s. d.). This percentage varies depending on the competition's location (Boston 42\%, New York 35\%, Berlin 20\%). The proportion of African women marathoners will probably increase and reinforce their dominance over other international athletes.

\section{Morphology and running speed}

The morphology of athletes has changed in recent years. Decreases in stature, body mass and BMI have occurred both in men and women runners (Norton \& Olds, 2001). Athletic performances require mix attributes, but a key factor might be biometric optimisation. This study shows an optimum BMI of $19.8 \mathrm{~kg} / \mathrm{m}^{2}$, even if the 10 best performers of all time have a BMI between 17.5 and $20.7 \mathrm{~kg} / \mathrm{m}^{2}$. Morphology and success in various disciplines is linked (O'Connor, Olds, \& Maughan, 2007; Sedeaud et al., 2012). Indeed, the BMI of marathoners is one of the lowest of all disciplines. Several studies have investigated biometrical characteristics of runners, especially those from Africa (Dennis \& Noakes, 1999; Kong \& de Heer, 2008; Larsen, 2003; Marino et al., 2000).

As regards thermoregulation, the superior running performance of African runners can be partly attributed to their lower BMI. Their ability to run faster is particularly notable in warm conditions where differences in performance are even greater between
Africans and non-Africans. This could be attributable to improved ability to release heat than heavier Caucasian runners (Marino et al., 2000). It has also been shown that small body size could be an advantage in distance running, particularly in the heat (Dennis \& Noakes, 1999; Marino et al., 2000). A greater proportion of lean body mass could account for differences in running performance in the heat between individuals of different sizes. It has been hypothesised that a rise of ambient temperature from 25 to $35^{\circ} \mathrm{C}$ causes larger and heavier runners to run slower because of greater accumulation of body heat that increases body temperature and so accelerates the onset of fatigue (Dennis \& Noakes, 1999; Marino et al., 2000).

Kong and de Heer (2008) claimed that the gracile limbs of Kenyan endurance runners contribute to improved performances because of their lower moments of inertia, and hence, required less internal mechanical work to be done during each running stride. In addition, the reduced ground contact time in these runners could improve running economy. Such a reduction in turn reduces braking forces to decelerate forward motion. The morphology of these athletes could be advantageous in terms of thermodynamics (Larsen, 2003). Indeed, their lighter legs compared with those of Nordic athletes' produced less heat and allowed an easier and faster stride.

\section{Seasonality}

The best performances occurred in late April (weeks 14 to 17 ) and late October (weeks 41 to 44 ). The major races occurred in London, Boston, Rotterdam and Paris for the first peak, and New York, Berlin, Chicago and Amsterdam for the second one. Best performances by men during these two periods are greater than those by women, $54.4 \%$ against $48.6 \%$, respectively. This can be explained by the dissociation of races between sexes. For women, peaks at weeks 4, 10 and 11 corresponded to marathons exclusively for women, respectively, in Osaka, Nagoya and Seoul (Osaka: start time 12:00 with mean temperature since 2001 of $7.3^{\circ} \mathrm{C} \pm 1.8^{\circ} \mathrm{C}$; Nagoya: start 09:00 with a mean temperature since 2005 of $8.8^{\circ} \mathrm{C} \pm 3.4^{\circ} \mathrm{C}$ ). However, the two peaks of the year match the optimal mean temperature condition for a marathon $\left(10^{\circ} \mathrm{C}\right)$ recorded during these periods in the northern hemisphere during races (El Helou et al., 2012). Furthermore, no world records and few good annual performances are established in the summer during the Olympic Games, Continental or International Championships. Despite the high standard of competition in these events, the lack of great performances can be explained by the temperatures during this period of year: they are too far from the optimum value during 
a marathon (Athens Olympic 2004: $25.6^{\circ} \mathrm{C}$, Beijing 2008: $25.0^{\circ} \mathrm{C}$ and world Championship Berlin 2009: $20.7^{\circ} \mathrm{C}$ ). Temperature has adverse effects on marathon runners. Heat causes a major alteration of cardiovascular, metabolic, neuromuscular and thermoregulatory function, and consequently, hyperthermia appears to be the key limiter of exercise performance in the heat (Galloway \& Maughan, 1997; Hargreaves, 2008). A study of the Stockholm Marathon (Vihma, 2010) and a large epidemiological study on all participants in the Boston, Chicago, New York, Paris, London and Berlin marathons from 2001 to 2010 confirmed this trend and showed that ambient temperature is influential (El Helou et al., 2012).

\section{Conclusion}

In this study, we have identified the main factors that will allow marathoner runners to improve. Each decile of the Top 100 has continued to progress over the last 20 years with similar annual variation. We have demonstrated that demography plays an important role in the improvement of top performances, with a progression of domination of African runners' performances. Furthermore, the best performances were made during periods characterised by lower temperatures (April and October) in response to optimal temperatures for endurance running (approximately $10^{\circ} \mathrm{C}$ ). Thus, when all these conditions are assembled, performance will probably continue to improve.

\section{Acknowledgements}

The authors thank INSEP teams for their full support.

\section{References}

Association of Road Racing Statisticians (ARRS). (s. d.). Association of Road Racing Statisticians ARRS. Consulté de. Retrieved from http://www.arrs.net/

Berthelot, G., Tafflet, M., El Helou, N., Len, S., Escolano, S., Guillaume, M., ... Toussaint, J. F. (2010). Athlete atypicity on the edge of human achievement: Performances stagnate after the last peak, in 1988. PloS One, 5(1), e8800.

Berthelot, G., Thibault, V., Tafflet, M., Escolano, S., El Helou, N., Jouven, X., ... Toussaint, J. F. (2008). The citius end: World records progression announces the completion of a brief ultra-physiological quest. PloS One, 3(2), e1552.

Bosch, A. N., Goslin, B. R., Noakes, T. D., \& Dennis, S. C. (1990). Physiological differences between black and white runners during a treadmill marathon. European Journal of Applied Physiology and Occupational Physiology, 61(1-2), 68-72.

Coetzer, P., Noakes, T. D., Sanders, B., Lambert, M. I., Bosch, A. N., Wiggins, T., \& Dennis, S. C. (1993). Superior fatigue resistance of elite black South African distance runners. Journal of Applied Physiology (Bethesda, Md.: 1985), 75(4), 1822-1827.
Dennis, S. C., \& Noakes, T. D. (1999). Advantages of a smaller bodymass in humans when distance-running in warm, humid conditions. European Journal of Applied Physiology and Occupational Physiology, 79(3), 280-284.

Desgorces, F.-D., Berthelot, G., El Helou, N., Thibault, V., Guillaume, M., Tafflet, M., ... Toussaint, J. F. (2008). From Oxford to Hawaii ecophysiological barriers limit human progression in ten sport monuments. PloS One, 3(11), e3653.

El Helou, N., Tafflet, M., Berthelot, G., Tolaini, J., Marc, A., Guillaume, M., ... Toussaint, J. F. (2012). Impact of environmental parameters on marathon running performance. PLoS ONE, 7(5), e37407.

Ely, M. R., Cheuvront, S. N., Roberts, W. O., \& Montain, S. J. (2007). Impact of weather on marathon-running performance. Medicine and Science in Sports and Exercise, 39(3), 487-493.

Field, A. (2009). Discovering statistics using SPSS (3rd ed.). London: Sage Publications Ltd.

Galloway, S. D., \& Maughan, R. J. (1997). Effects of ambient temperature on the capacity to perform prolonged cycle exercise in man. Medicine and Science in Sports and Exercise, 29(9), 1240-1249.

Hargreaves, M. (2008). Physiological limits to exercise performance in the heat. Journal of Science and Medicine in Sport/ Sports Medicine Australia, 11(1), 66-71.

Joyner, M. J., Ruiz, J. R., \& Lucia, A. (2011). The two-hour marathon: Who and when? Journal of Applied Physiology (Bethesda, Md.: 1985), 110(1), 275-277.

Kong, P. W., \& de Heer, H. (2008). Anthropometric, gait and strength characteristics of Kenyan distance runners. Journal of Sports Science and Medicine, 7, 499-504.

Larsen, H. B. (2003). Kenyan dominance in distance running. Comparative Biochemistry and Physiology. Part A, Molecular $\mathcal{E}$ Integrative Physiology, 136(1), 161-170.

Lippi, G., Favaloro, E. J., \& Guidi, G. C. (2008). The genetic basis of human athletic performance. Why are psychological components so often overlooked? The Journal of Physiology, 586(Pt 12), 3017; author reply 3019-3020.

Macarthur, D. G., \& North, K. N. (2005). Genes and human elite athletic performance. Human Genetics, 116(5), 331-339.

Marino, F. E., Mbambo, Z., Kortekaas, E., Wilson, G., Lambert, M. I., Noakes, T. D., \& Dennis, S. C. (2000). Advantages of smaller body mass during distance running in warm, humid environments. Pflügers Archiv: European Journal of Physiology, 441(2-3), 359-367.

Nevill, A. M., \& Whyte, G. (2005). Are there limits to running world records? Medicine and Science in Sports and Exercise, 37 (10), 1785-1788.

Norton, K., \& Olds, T. (2001). Morphological evolution of athletes over the 20th century: Causes and consequences. Sports Medicine (Auckland, N.Z), 31(11), 763-783.

O'Brien, M. (1985). Women and sport. Applied Ergonomics, 16(1), 25-39.

O'Connor, H., Olds, T., \& Maughan, R. J. (2007). Physique and performance for track and field events. Journal of Sports Sciences, 25(suppl. 1), S49-60.

Olympics at Sports Reference. (s. d.). Olympics at Sports-FootballReference.com. Consulté avril 18, 2012, de. Retrieved from http://www.sports-reference.com/olympics/

Onywera, V. O., Scott, R. A., Boit, M. K., \& Pitsiladis, Y. P. (2006). Demographic characteristics of elite Kenyan endurance runners. Journal of Sports Sciences, 24(4), 415-422.

Rivera, M. A., Dionne, F. T., Simoneau, J. A., Pérusse, L., Chagnon, M., Chagnon, Y., ... Bouchard, C. (1997). Musclespecific creatine kinase gene polymorphism and $\mathrm{VO}_{2} \max$ in the HERITAGE Family Study. Medicine and Science in Sports and Exercise, 29(10), 1311-1317.

Saltin, B., Kim, C. K., Terrados, N., Larsen, H., Svedenhag, J., \& Rolf, C. J. (1995). Morphology, enzyme activities and buffer 
capacity in leg muscles of Kenyan and Scandinavian runners. Scandinavian Journalof Medicine E Sciencein Sports, 5(4), 222-230.

Saltin, B., Larsen, H., Terrados, N., Bangsbo, J., Bak, T., Kim, C. K., ... Rolf, C. J. (1995). Aerobic exercise capacity at sea level and at altitude in Kenyan boys, junior and senior runners compared with Scandinavian runners. Scandinavian Journal of Medicine $\mathcal{E}$ Science in Sports, 5(4), 209-221.

Schmidt, W., Heinicke, K., Rojas, J., Manuel Gomez, J., Serrato, M., Mora, M., ... Keul, J. (2002). Blood volume and hemoglobin mass in endurance athletes from moderate altitude. Medicine and Science in Sports and Exercise, 34(12), 1934-1940.

Scott, R. A., Georgiades, E., Wilson, R. H., Goodwin, W. H., Wolde, B., \& Pitsiladis, Y. P. (2003). Demographic characteristics of elite Ethiopian endurance runners. Medicine and Science in Sports and Exercise, 35(10), 1727-1732.
Sedeaud, A., Marc, A., Schipman, J., Tafflet, M., Hager, J.-P., \& Toussaint, J.-F. (2012). How they won Rugby World Cup through height, mass and collective experience. British Journal of Sports Medicine, 46(8), 580-584.

Vihma, T. (2010). Effects of weather on the performance of marathon runners. International Journal of Biometeorology, 54 (3), 297-306.

Weston, A. R., Karamizrak, O., Smith, A., Noakes, T. D., \& Myburgh, K. H. (1999). African runners exhibit greater fatigue resistance, lower lactate accumulation, and higher oxidative enzyme activity. Journal of Applied Physiology (Bethesda, Md.: 1985), 86(3), 915-923.

Williams, A. G., \& Folland, J. P. (2008). Similarity of polygenic profiles limits the potential for elite human physical performance. The Journal of Physiology, 586(1), 113-121. 